\title{
Exploring Academic Performance: Looking beyond Numerical Grades
}

\author{
Martín Sanz Noemy*, Rodrigo Inés G., Izquierdo García Cristina, Ajenjo Pastrana Patricia
}

Department of Psychology, University Francisco de Vitoria, Spain

Copyright $\mathrm{C} 2017$ by authors, all rights reserved. Authors agree that this article remains permanently open access under the terms of the Creative Commons Attribution License 4.0 International License

\begin{abstract}
Academic performance has always been associated to the evaluation tests results, which are those corresponding to student's IQ, and leaving aside other personal characteristics. Among such characteristics, the importance of emotional intelligence is worth highlighting (management, facilitation, understanding and perception), dimensions associated to personality traits (emotional impulsiveness, respect for others, sociability, negotiating skills, openness to experience, self-confidence) and, of course, the meaning of life, since the creation of meaning is related to each person's individual development, in hand with other processes such as identity, relationships and life goals. The objective of this project is to study the role of these dimensions in the learning process and development of students, which may predict future performance. To do so, we have conducted an observational study with 217 psychology students at the Francisco de Vitoria University, which identifies the importance of each characteristic relative to academic performance. The results show that the aforementioned theoretical models are isolated, making it necessary to include other variables, such as the meaning of life and emotional intelligence to explain academic performance.
\end{abstract}

Keywords Academic Performance, Meaning of Life, Emotional Intelligence, Personality

\section{Introduction}

Today, there is a clear need for education to learn about the factors that influence a student's academic performance, considering the performance to be the quantitative result obtained during the learning process, based on the evaluations carried out by the teachers through objective test evaluations [1]. The latest patterns in this area highlight the importance of considering other variables beyond intellectual capabilities. These trends are supported by several points of research that show that academic performance is not only associated with intellectual quotient (IQ), but there are multiple variables and dimensions to which a certain predictive value can be attributed. For this reason, the objective of this report is to extend the existing source of knowledge when it comes to explaining or understanding academic performance, which is why we will analyze the importance of emotional intelligence, personality and the meaning of life in such performance.

Along the years, there have been many studies devised in aims to identify the variables that can predict academic achievement. Among the first factors we can spot personality: a concept etymologically comes from the Latin "prospon" and means "mask", referring to the masks that actors used in theatres in Ancient Greece [2]. The Spanish Royal Academy of Language defines the construct as "the individual difference that makes a person and differentiates them from others" [3]; from a psychological stand point, personality is defined as the characteristic or general traits of people to relate and interact with the world according to the interaction between genetics and environmental factors [4] that are reflected steadily over time in different contexts [5]. A study carried out by Savage [6] is among the first investigations on personality and academic performance, which shows the relation between low academic performance and Neuroticism; similar results have been found in current studies [7-10]. After the study carried out by Savage, personality has been marked as one of the main axes to explain academic achievement, and different studies have been related similar ideas, as that of Blickle [11], who defines Big Five personality traits, "openness to experience" had an important positive relation to academic achievement $[11,12]$, which was supported by a study carried out by De Guzmán, Calderón and Cassaretto [13]. Said study shows that students with high levels of academic performance obtained higher scores in traits of "penness to experience", "consciousness" and "extraversion", while showing lower levels in "neuroticism"; the one carried out by Pérez, Cupani and Ayllon [11] found that the personality characteristic for "responsibility" helps to explain academic performance [11]. In addition, there are studies that suggest that personality is 
associated to variables that strongly influence academic performance, as can be motivation, intelligence and self-efficacy $[14,15]$; moreover, there is a general belief that personality is not directly associated with academic achievement, but rather is proper adjustment to the educational environment [16]. Despite the aforementioned studies in which the relation between both variables, personality and academic performance, has been verified, most investigations provide correlated relations, making it difficult to refer to cause-effect relations, or to determine the specific effect that one has trough the other [17].

Aside from general traits that people use to interact with each other and the world, emotions and feelings are characteristics that cannot be ignored in the human being, as they determine and modify their behaviour, and even their health, proving to hold an important role in life [18]. Despite its importance, it was not until the $20^{\text {th }}$ century that emotional intelligence (EI) became the center of psychological studies, both in clinical practice and in the academic world. Emotional intelligence is defined as the ability to perceive and express emotions, applied to facilitate thinking, to understand and reason through them and to regulate them in oneself and in others [19]. Goleman [20] defines emotional intelligence (EI) from a broad perspective, considering it as a combination of attributes closely related to personality. It differs from IQ and, in general, it is related to academic performance and other competences [21]. Furthermore, EI predicts, in most cases, the ability people have to adapt with their surroundings [21] and is strongly related with success in life, as it includes emotional, social and even personal skills [22].

Thus, the academic world is one of the best means to prove such ideas [21]. The results provided by the studies show the importance of bearing in mind emotional skills, not only in the personal aspect, but in the academic world. Barchard's (2003) results support that EI levels in university students predicted their academic performance at the end of the school year [23], link that has been found in many investigations [24-29]. Even, Pérez and Castejón (2006) prove that a significant correlation exists between EI and academic achievement, making the latter EI, the trait that predicts at a larger scale a person's academic performance, instead of a standard achievement survey [30]. Lastly, one of the studies with a higher number of participants that goes on to prove the relation between both characteristics is that carried out by Pulido [31], who conducted the study with 1.186 subjects, indetifying a relation of reciprocity when predicting EI scores and academic performance. Such studies explain the importance of extending EI education in the academic world, in order to educate students to be well prepared for an ordinary day-to-day life [23].

As established above, there are a high number of studies in which EI and personality have been related to academic performance, but there is no evidence of studies related to the influence of the meaning of life on academic performance. Viktor Frankl [32], has been the main promoter of the importance of this variable. The meaning of life is defined as "the affective-cognitive perception of values that invite or guide a person to act in one way or another in specific or general situations of life, giving coherence and personal identity" [33], (Martínez quoting Martínez Ortiz \& Castellanos, 2013, p. 73). It is the first motivation of a human being and is a part of his existential nature [34-36].

Frankl states that, when people have or feel a meaning to their lives, as well as a purpose for life, they feel better psychologically [37], and that, according to Frankl, people who find this meaning to their life is a motivational push, thanks to which self-realization can be achieved [38]. People who feel a strong meaning to their lives can comprehend and are better prepared for life situations, as well as have more autonomy and determination [34]. On the other hand, those who are unable to find a meaning to their lives experience a sense of hopelessness, disorientation and existential emptiness, which could result in a perception of lack of control over their lives, monotony, lack of goals, apathy or feelings of uselessness, which could lead the person, as an extreme measure, to suicide [38,39]. This becomes evident in the results of the research carried out by Edwars and Holden (2003), in which the meaning of life weakened, along with the forms of coping with different traits, the suicidal manifestations [40]. The influence of the meaning of life has been confirmed in previous studies: it can be, for example, set as a close predicament of psychological well-being [41, 42]. This is based on the consideration that psychological well-being is something beyond pleasure or happiness, as perceiving that life has a value or goals generates these same feelings [41]. This result is in line with that found by Ryff and Keyes [43], who shows the positive aspect of establishing goals and projects related to the meaning of life, which favours the feeling of a full and meaningful life. With all of this, the importance of the meaning of life for human beings is revealed, as Lukas said, in his in words (2001): "When questioning the sense of vitality in the meaning of a person's own existence (...) when the experience of a sense vanishes, the affective ground is given traded" $[38,39]$. Additionally, this experience can be both positive and negative for the person, since the important lesson is that, whatever is the outcome may be, the person believes that what has happened was a condition to reach well-being [44, 45].

The meaning of life, understood as logotherapy does, implies that the person has goals and a purpose in life, as well as a feeling of usefulness and freedom; we must have in mind that this meaning is not given, but must be discovered in every task and in everyday life [46]. Thus, meaning underlies in the choice of a university degree over another, which is accompanied by a goal to be fulfilled in the future, if the person has found the meaning to that career and what their work means and daily involvement with that purpose, making their academic performance higher. In fact, in this vital stage, to find a goal could improve personal aspirations [47]. The results found by Bailey and Phillips [48] support 
this idea, considering that they show significant relations among internal motivation and the meaning of life. On the other hand, the meaning of life is not constant throughout the years, but changes according to the tasks that a person must face on a day-to-day basis and depending on the incorporation of new values or beliefs that we add to our being [46, 49, 50]. Although it is essential to find the meaning of life in all the stages of the vital cycle it is particularly important to have this meaning in periods of vital crisis such as during university years, where the influence of this meaning is higher. In fact, it has been found that university students show higher scores in terms of meaning of life than the rest of the population [47].

The study has been designed with the aim to assess the extent at which academic performance at a university level can be explained not only by personality and emotional intelligence, as previous research shows, but also by the meaning of life. The hope is to find that academic performance could be explained, mainly, by life, and then by emotional intelligence and personality.

\section{Materials and Methods}

\subsection{Participants}

The sample used for this study is $n=217$, with an average age of 20.53 and a ST of 2.69 , being 18 the minimum age and 47 the maximum. $80.6 \%$ were women and the $19.4 \%$ were men.

The participants are students in the Psychology Degree at the Francisco de Vitoria University in Madrid, which is a private university. Participants are distributed in the four grades of the degree, $15.7 \%$ of them being in year $1 \mathrm{~A}, 10.6 \%$ in year $1 \mathrm{~B}, 18 \%$ in year $2 \mathrm{~A}, 14.3 \%$ in $2 \mathrm{~B}, 13.4 \%$ in $3 \mathrm{~A}$, $11.5 \%$ in $3 \mathrm{~B}$ and, lastly, $16.6 \%$ in their $4^{\text {th }}$ year.

\subsection{Factors and Instruments}

This is a non-experimental observational descriptive study and a field experiment as the environmental conditions and the variables were not modified. Likewise it is a cross-sectional study, as because the data has been collected at a specific period in time. The individual variables to be considered are emotional intelligence, personality and meaning in life. Meanwhile the conditioning variable is academic performance.

Emotional Intelligence: This variable has been measured by a questionnaire which has been made applying some questions from the Mayer-Salovey-Caruso Emotional Intelligence Test (MSCEIT) [51], corresponding to each characteristics of the test, which are emotional perception, emotional facilitation, comprehension and emotional management (see table 1). The questionnaire is made up of 25 components, on a 5-point Likert scale, going from 1, the "never" option, to 5, corresponding to option "always". The internal consistency of the questionnaire, measured by the Cronbach's Alpha, is .706 [52]. In this study, Cronbach's Alpha is .768. Regarding the validity of the questionnaire, we can determine that it is capable of distinguishing between those who are perceived by others as a person that can favour personal growth [52].

Table 1. Example of items of the instrument to measure emotional intelligence

\begin{tabular}{|c|c|}
\hline Characteristic & Example Question \\
\hline Emotional perception & Are you always aware of your emotions? \\
\hline Emotional facilitation & Can you change easily how you feel? \\
\hline $\begin{array}{c}\text { Emotional } \\
\text { comprehension }\end{array}$ & $\begin{array}{c}\text { Do you use your emotional knowledge to } \\
\text { understand people? }\end{array}$ \\
\hline $\begin{array}{c}\text { Emotional } \\
\text { management }\end{array}$ & Your decisions are usually right? \\
\hline
\end{tabular}

Personality: In this section, the questionnaire measures personality, assessing five dimensions related to social interactions [53]. It is made up of 44 items with a 5-point Likert scale ranging from 1, "totally disagree", to 5, "totally agree". The five areas that this questionnaire assesses are impulsivity, sociability, openness to experience, security and conflict resolution styles. The original questionnaire shows examples of reliability (Cronbach's Alpha) of more than .75. The scales goodness-of-fit of confirmatory factor analysis are considered acceptable [53]. The internal consistency of the characteristics in the present study ranges from .511 to .733 .

Purpose in life: To measure this variable, a section (A) of the the Spanish version of PIL (Purpose-in-Life Test) was applied [54]. (Noblejas, 1994). The test is made up of three parts. The first one, with 20 items, the subject must be placed on a Likert scale, from 1 to 7, being each one opposite situations. The higher scores on the test, the greater meaning of life the person has. The second and the third parts are open questions that have a more clinical objective, rather than research. The reliability of the part A of the test has been studied in different situations, always resulting in a Cronbach's Alpha scale of more than .85 [36, 54, 55, 56]. The questionnaire's internal consistency in the study is .892 (Cronbach alpha).

Academic year of the Psychology degree student: $1^{\text {st }}$ year, $2^{\text {nd }}$ year, $3 r^{\text {d }}$ year and $4^{\text {th }}$ year.

A student's academic performance: The average grade, measured up to the time of this study, has been used for this variable. Exams, practical exercises and a final project have been taken into account when calculating an average grade in each subject. The implementation of such objective tests results in a quantitative score that is included in a range from 0 to 10 , and determines the level of performance obtained by the student [1].

\subsection{Procedure}

A booklet was made with different sections for data collection. First of all, the informed consent, where the 
participants were informed about the objective of the research, the wilfulness and the confidentiality of the data collected. After giving their consent, the first step was the personality test, followed by the emotional intelligence questionnaire and, lastly, part A of the PIL test.

Data was collected in October and November of the 2015/2016 school year, in the classrooms of the Biosanitary Sciences department of the Francisco de Vitoria University in Madrid

\subsection{Data Analysis}

Hierarchical multiple regression analyses have been carried out, whereby academic performance is the dependent variable or response $(\mathrm{Y})$ and the meaning of life, emotional intelligence, impulsivity, sociability, openness to experience, safety and negotiation skills and the academic course are the independent or predictive variables $(\mathrm{Xn})$. This method is used when there are a large number of variables, but there is no previous hypothesis of what the relevant variables will be [57].

\section{Results}

Multiple linear regression of academic performance is measured from the meaning of life, emotional intelligence, impulsivity, sociability, and openness to experience, security, conflict resolution style and the academic year.

The results indicate that the process was carried out in 4 steps. In the first one, the chosen variable was the trait purpose in life; in the second step, openness to experience; in the third, academic year and in the fourth, conflict resolution means.

The $\mathrm{R}^{2}$ value was .22 , which indicates that $22 \%$ of the academic achievement variability is explained by purpose in life (PL), openness to experience (OE), academic course (AC) and conflict resolution style (CRS).

The analysis suggests the next regression equation (see table 1) in direct punctuations:

Prognosis (academic performance) $=3.71+.02(\mathrm{PL})-.15$ $(\mathrm{OE})+.26(\mathrm{AC})+.07(\mathrm{CRS})($ see table 1$)$
All variables included in the equation present significant regression coefficients (see table 2).

Purpose in life contributes with $7 \%$, openness to experience with $10.8 \%$, academic course with $4.5 \%$ and conflict resolution style with $2.5 \%$

In regards to the verification of assumptions, results show that there is no collinearity, since there is no congruency between the meaning of the F statistic and the significance of the regression coefficients; there are no regression coefficients with different signs than those expected and, also, there are no typified coefficients with values greater than one. Moreover, the tolerance values are between .800 and .963 , and the FIV values between 1.038 and 1.249. As to the independency assumption, the Durbin - Watson statistic is 2.07. In addition, the normality assumption, the typified residues graphic and the histogram indicate a very similar distribution to the normal one. In regards to homoscedasticity assumptions, the prognostic and residues dispersion diagrams show a homogeneously pint-cloud distribution.

Lastly, there are no atypical and influential cases, the residual studentized have values between -2.77 and 2.26, the highest influence value is .18 , the Cook distance is .05 , and the eliminate studentized residuals oscillate between -2.82 and 2.28 .

\section{Comments and Conclusions}

We hoped to find that academic performance could be explained, mainly, by the purpose in life, and subsequently by emotional intelligence and personality; however, results only support in part the first hypothesis. In fact, purpose in life and some personality traits influence in university students' academic performance, as well as in their academic year. The purpose in life is the variable which explains, at a higher percentage, the variance, followed by openness to experience, academic year and conflict resolution style. Emotional intelligence could not explain academic achievement in a significant way, remaining this variable out of the equation.

Table 2. Significant regression coefficient

\begin{tabular}{|c|c|c|c|c|}
\hline & Not typified coefficients & $\begin{array}{c}\text { Typified } \\
\text { coefficients }\end{array}$ & $\mathrm{t}$ & Sig. \\
\hline Purpose in life & .025 & .299 & 4.565 & .000 \\
\hline Openness to experience & -.148 & -.368 & -5.359 & .000 \\
\hline Academic year & .259 & .218 & 3.487 & .001 \\
\hline Conflict resolution style & .073 & .175 & 2.548 & .012 \\
\hline
\end{tabular}


The results do not confirm the hypothesis completely, but are coherent with previous research, where the EI variable showed a confusing relation with academic performance, as is shown by studies carried out by Newsome, Day and Catano [58], Parker, Summerfeldt, Hogan and Majeski [26] and Otero, Martín, León and Vicente [59], where there is no significant relation between academic performance and emotional intelligence. One of the possible explanations to understand such results is that previous studies, as in the one herein, the sample is all from university students, who are in a stage of their lives where they suffer a lot of changes and transactions that can affect their emotional intelligence, more than if they were in a different phase of their lives [23].

In terms of predictive variables that refer to personality, previous studies show contradictory results. On the one hand, the study carried out by Guzmán, Calderón and Cassaretto [13], report a positive relation among openness and academic performance, specifically, a greater openness to experience showing higher levels in academic performance. On the other hand, the results found in the present study reflect a negative relation between these variables, openness and academic achievement.

A possible explanation for this contradiction could be given by the implementation results of academic performance. Referring to openness experience conceptualization, this is associated with creativity, imagination and divergent thinking [60-62]. Thus, if academic achievement is assessed with a writing test that requires memorizing theoretical contents, the openness to experience is of no relevance, and can even be detrimental to academic achievement. Considering that a greater openness to experience makes a student prepared to experiment different situations, it will be difficult to focus on memorizing mere content. If, on the other hand, we focus on an evaluation based on learning by projects, a personal characteristic which requires, for example creativity, imagination and divergent thinking, where the openness experience could be considered the key for performance, assuming an advantage for people which obtained higher scores in this variable. In this regard, a form of resolution of conflict style based on cooperation can also be a good predictor of academic achievement. In addition, it shows a positive relation between both variables, that means that those who look for support from others to solve a conflict or to improve and move on, can be expected higher academic achievement, as they encourage themselves not only from their knowledge but also from what other can provide for them to continue learning. This result is coherent with previous researches that prove the importance of cooperative learning on the academic results [63-65]. If we also consider learning by projects, as mentioned above, this supports the results that state that group work inspires individual knowledge, not only of theoretical content, due to imagination, creativity and different points of view, that improve academic performance. Moreover, the conflicts that appear during group work are an opportunity for students to improve their negotiation and assertiveness skills, which can improve their social abilities as conflict resolutions promote autonomy, environment adaptation and learning capacity [66]. All these results show the importance of schoolroom cooperation and the development of team work to improve academic achievement.

Referring to the meaning of life predictive ability, as not knowing previous results by the absence of studies, it is not possible to compare the obtained results. The present study proves the importance of bearing in mind this variable to predict academic performance, so it is therefore necessary to continue studying the influence of this variable in the academic world. To have a goal and clear objectives in life, and to know the role that each individual plays in a given moment seems to be important to get better results. In fact, having goals and clear objectives is related to high internal motivation, which in turn, according to previous studies, is related to a great meaning of life [48]. This is due to the fact that personal identity is formed through the attainment of goals, being also important the goals on the academic environment and the life stage itself [67], that affect also in personal values, rising the meaning of life [68].

This allows us to explain why an academic year can predict academic performance. Results show that as the student progresses in the degree, their academic performance increases. As the years' pass, students have clearer objectives and their commitment to their studies is greater, which is intrinsically related to the meaning of life. Thus, they confirm the studies carried out by different authors where people increase their orientation towards achievement as they become older $[69,70]$ and significantly affects the meaning of life. Also, these results may be due to the personal growth that students experience during these years, as the course of academic and life situations which they must face are an approach to the life they desire to have. Likewise, these situations represent a transitory stage for values, which could remain or change according to the person, but become, in any case, more real, personal and committed, leading the individual to increase his meaning of life [71].

Despite the importance of the results, it is necessary to consider that the sample used does not allow for a generalization of these, as all the students are from the same university and the same degree. Furthermore, psychology students may have more knowledge about the variables with respect to other university students. Therefore, in future studies there should be an increase in the sample representativeness with the aim of ascertaining whether the results remain the same. Besides, emotional intelligence has been analysed as a whole variable, without considering its traits, which could have a repercussion on the low significant index obtained, because dimensions like emotional comprehension or emotional management may be related with the meaning of life. Moreover, for future studies, it would be necessary to continue studying the relation between these variables attending to the human learning evaluation, as when the academic achievement refers simply 
to an objective test like normal exams, the variables that influence where are not the same as when the academic achievement refers to a test in which the students should use other variables, such as creativity. Finally, in any case, knowing which variables are influential in academic performance is necessary because this knowledge will allow improvement in the teaching - learning processes.

\section{REFERENCES}

[1] Garbanzo, G. M. (2007). Factores asociados al rendimiento académico en estudiantes universitarios, una reflexión desde la calidad de la educación superior pública. Revista educación, 31(1), 43-63. http://dx.doi.org/10.15517/revedu.v31i1.1252

[2] Actis, C. C., \& Sosa, J. R. (2008). Revisión histórica del concepto de trastorno de la personalidad. En Anales de psiquiatría, 24 (5), 223-232.

[3] Real Academia Española. (2001). Diccionario de la lengua española (22.a ed.). Consultado en http://www.rae.es/rae.html

[4] Vinet, E. V., \& Forns i Santacana, M. (2006). El Inventario Clínico para Adolescentes de Millon (MACI) y su capacidad para discriminar entre población general y clínica. Psykhe, 15(2), 69-80.

http://dx.doi.org/10.4067/S0718-22282006000200007

[5] Del Barrio, V. (1992), Evaluación de las características de la personalidad, en: Fernández-Ballesteros, R., Introducción a la evaluación psicológica II, Madrid: Pirámide.

[6] Savage, R.D. (1966) Personality factors and academic attainment in junior school children. British Journal of Educational Psychology, 35, 91-92

http://dx.doi.org/10.1111/j.2044-8279.1966.tb01844.x

[7] Nácher, V. (2002). Personalidad y rendimiento académico. Jornades de Foment de la Investigació de la Universitat Jaume I. España.

[8] Chamorro-Premuzic, T., \& Furnham, A. (2003). Personality predicts academic performance: Evidence from two longitudinal university samples. Journal of research in personality, 37(4), 319-338.

[9] Kim, S., Fernandez, S., \& Terrier, L. (2017). Procrastination, personality traits, and academic performance: When active and passive procrastination tell a different story. Personality and Individual Differences, 108, 154-157.

http://dx.doi.org/10.1016/j.paid.2016.12.021

[10] Urbano Valverde, I. G., \& Tingo Cali, T. V. (2017). Rasgos de la Personalidad y Rendimiento Académico en los estudiantes de la Unidad Educativa “'Isabel De Godin”' (tesis doctoral). Universidad Nacional de Chimborazo, Ecuador

[11] Pérez, E., Cupani, M., \& Ayllón, S. (2005). Predictores de rendimiento académico en la escuela media: habilidades, autoeficacia y rasgos de personalidad. Avaliação Psicológica, 4(1), 01-11.

[12] Malykh, S. (2017). The role of Personality Traits and Intelligence in Academic Achievement of Russian High School Students. Procedia-Social and Behavioral Sciences, 237, 1304-1309.

http://dx.doi.org/10.1016/j.sbspro.2017.02.214
[13] De Guzmán, I. N., Calderón, A., \& Cassaretto, M. (2003). Personalidad y rendimiento académico en estudiantes universitarios. Revista de Psicología, 21(1), 119-143.

[14] Ackermn, P., \& Heggestad, E. (1997). Intelligence, personality, and interests: Evidence for overlapping traits. Psychological Bulletin 121, 219-245.

[15] Caprara, G. V., Barbaranelli, C., Pastorelli, C., \& Cervone, D. (2004). The contribution of self-efficacy beliefs to psychosocial outcomes in adolescence: predicting beyond global dispositional tendencies. Personality and Individual Differences, 37,751-763

[16] Allik, J., \& Realo, A. (1997). Intelligence, academic abilities, and personality. Personality and Individual Differences, 23,809-814.

[17] Digman, J. M. (1989). Five robust trait dimensions: Development, stability, and utility. Journal of personality, 57(2), 195-214.

http://dx.doi.org/10.1111/j.1467-6494.1989.tb00480.x

[18] Ortega, M. C. (2010). La educación emocional y sus implicaciones en la salud [Emotional education and its implications for health]. REOP, 21(2), 462-470.

[19] Mayer, J. D., Salovey, P., Caruso, D., \& Cherkasskiy, L. (2011). Emotional intelligence The Cambridge handbook of intelligence (pp. 528-549). New York

[20] Goleman, D. (1995). Inteligência emocional: a teoria revolucionária que define o que é ser inteligente. Rio de Janeiro: Objetiva.

[21] Pérez, A. M., Gilar, R., \& Castejón, J. L. (2006). Aprendizaje complejo: el papel del conocimiento, la inteligencia, motivación y estrategias de aprendizaje. Psicothema, 18(4), 679-685.

[22] Bermúdez, M. P., Álvarez, I. T. \& Sánchez, A. (2003). Análisis de la relación entre inteligencia emocional, estabilidad emocional y bienestar psicológico. Universitas Psychologica, 2(1), 27-32.

[23] Extremera, N., \& Fernández-Berrocal, P. (2004). El papel de la inteligencia emocional en el alumnado: evidencias empíricas. Revista electrónica de investigación educativa, 6(2), 1-17.

[24] Vela, R. H. (2004). The role of emotional intelligence in the academic achievement of first years college students. Dissertation Abstracts International Section A: Humanities and Social Sciences, 64(11-A) 2004, 3978.

[25] Sternberg, R. (2004). Theory Based University Admissions Testing for a New Millennium. Educational Psychologist, 39(3), 185-198. http://dx.doi.org/10.1207/s15326985ep3903 4

[26] Parker, J. D. A., Summerfeldt, L. J., Hogan, M. J. \& Majeski, S. A. (2004). Emotional intelligence and academic success: examining the transition from high school to university. Personality and Individual Differences, 36 (1), 163-172.

[27] Mestre, J.M., Guil, M.R., \& Gil-Olarte, P. (2004). Inteligencia emocional: Algunas respuestas empíricas y su papel en la adaptación escolar en una muestra de alumnos de secundaria. R.E.M.E. [On line], 7(16). Disponible en http://reme.uji.es/articulos/avillj3022906105/texto.html 
[28] Drago, J.M. (2005). The relationship between emotional intelligence and academic achievement in nontraditional college students. Dissertation Abstracts International: Section B: The Sciences and Engineering, 65(9-B), 4811.

[29] Gil-Olarte P., Guil R., Mestre J.M., \& Nuñez I. (2005). La inteligencia emocional como variable predictora del rendimiento académico. Libro de Actas del IX Congreso Nacional de Psicología Social (Vol 5, pp.351-357)

[30] Pérez, N., \& Castejón, J. L. (2006). Relaciones entre la inteligencia emocional y el cociente intelectual con el rendimiento académico en estudiantes universitarios. Reme, 9(22), 1-27.

[31] Pulido Acosta, F. (2016). Miedo, inteligencia emocional y rendimiento académico en el contexto educativo pluricultural de Ceuta (Tesis Doctoral). Universidad de Granada, España.

[32] Frankl, V. E. (1963). Man's Search for Meaning; an Introduction to Logotherapy: Of From Death-camp to Existentialism. Translated by Ilse Lasch. Pref. by Gordon W. Allport. Beacon Press.

[33] Martínez Ortiz, E., \& Castellanos Morales, C. (2013). Perception of the Meaning of Life among Colombian University Students. Pensamiento Psicológico, 11(1), 71-82.

[34] Marco, J. H., García-Alandete, J., Pérez, S., \& Botella, C. (2014). El sentido de la vida como variable mediadora entre la depresión y la desesperanza en pacientes con trastorno límite de la personalidad. Behavioral Psychology / Psicología Conductual, 22(2), 293-305.

[35] Frankl, V. E. (2003). Ante el vacío existencial. Barcelona: Herder.

[36] García-Alandete, J. (2014). Análisis factorial de una versión española del Purpose-In-Life Test, en función del género y edad. Pensamiento psicológico, 1, 83-98.

[37] Steger, M.F. (2012). Making Meaning in Life. Psychological Inquiry, 23, 381-385.

http://dx.doi.org/10.1080/1047840X.2012.720832

[38] García-Alandete, J., Gallego-Pérez, J. F., \& Pérez-Delgado, E. (2009). Sentido de la vida y desesperanza: un estudio empírico. Universitas Psychologica, 8(2), 447-454.

[39] Lukas, E. (2001). Paz vital, plenitud y placer de vivir: Los valores de la logoterapia. Barcelona: Paidós.

[40] Edwards, M. J., \& Holden, R. R. (2003). Coping, meaning in life, and suicidal manifestations: Examining gender differences. Journal of Clinical Psychology, 59(10), $1133-1150$.

[41] García-Alandete, J. (2015). Does Meaning in Life Predict Psychological Well-Being? An analysis using the Spanish versions of the Purpose-In-Life Test and the Ryff's Scales. The European Journal of Counselling Psychology, 3(2), 89-98.

[42] Velásquez, C., Montgomery, W., Montero, V., Pomalaya, R., Ch, A. D., Araki, R., \& Reynoso, D. (2008). Bienestar psicológico, asertividad y rendimiento académico en estudiantes universitarios sanmarquinos. Revista de Investigación en Psicología, 11(2), 139-152.

[43] Ryff, C. D. \& Keyes, C. L. M. (1995). The structure of psychological well-being revisited. Journal of Personal and Social Psychology, 69, 719-727
[44] Coke, M. M. (1992). Correlates of life satisfaction among elderly African Americans. Journal of Gerontology, 47(5), 316-320. http://dx.doi.org/10.1093/geronj/47.5.P316

[45] Frankl, V. E. (2003). Ante el vacío existencial. Barcelona: Herder.

[46] Bonilla, F. S., \& Brenes, M. R. (1997). Sentido de la vida en personas mayores de 50 años. Reflexiones, 59(1), 4.

[47] Moreno, M. \& Rodríguez, M. I. (2010). Sentido de la vida, inteligencia emocional y salud mental en estudiantes universitarios. XI Congreso Virtual de Psiquiatría. Interpsiquis

[48] Bailey, T. H., \& Phillips, L. J. (2016). The influence of motivation and adaptation on students' subjective well-being, meaning in life and academic performance. Higher Education Research \& Development, 35(2), 201-216.

[49] Thorson, J. (1995). Aging in a changing Society. U.S.A.: Wadsworth Pu. Co.

[50] Lehr, U. (1980). Psicología de la Senectud. Barcelona: Heder.

[51] Extremera Pacheco, N., \& Fernández-Berrocal, P. (2002). Adaptación al castellano del Mayer-Salovey-Caruso Emotional Intelligence Test (MSCEIT): Users Manual. Toronto: Multi-Health Systems.

[52] Martín, N., Rodrigo, I. G., \& Izquierdo, C. (2015, noviembre). Una visión humanista de la convivencia: Las relaciones más allá de la conducta. I Congreso Internacional de Psicología y Psicoterapias Humanistas. Barcelona. España

[53] Martín, N. \& Erdozain, J. (2014). Sistema de Evaluación Bejoins. No Patente. M-005631/2014. Madrid: España. Registro territorial de la propiedad intelectual.

[54] Noblejas de la Flor, M. (1994). Logoterapia. Fundamentos, principios y aplicación. Una experiencia de evaluación del "logro interior de sentido". Tesis doctoral, no publicada. Universidad Complutense de Madrid, Madrid, España.

[55] García-Alandete, J., Martínez, E. R., \& Nohales, P. S. (2013). Estructura factorial y consistencia interna de una versión española del Purpose-In-Life Test. Universitas Psychologica, 12(2), 517.

[56] Noblejas, M. A. (2011). El sentido de la vida, dimensión evolutiva. Hallazgos empíricos en la baremación del test PIL (Purpose In Life) en España. Journal of Transpersonal Research, 3(1), 30-38.

[57] Pardo, A. \& San Martín, R. (2010). Análisis de datos en ciencias sociales y de la salud II. Madrid: Síntesis.

[58] Newsome, S., Day, A. L. \& Catano, V. M. (2000). Assessing the predictive validity of emotional intelligence. Personality and Individual Differences, 29(6), 1005-1016. http://dx.doi.org/10.1016/S0191-8869(99)00250-0

[59] Otero Martínez, C., Martín López, E., León del Barco, B., \& Vicente Castro, F. (2009). Inteligencia emocional y rendimiento académico en estudiantes de enseñanza secundaria. Diferencias de género. Revista Galego-Portuguesa de Psicoloxía e Educación, 17 (1,2), 1138-1163.

[60] Costa, P. T., Jr. \& McCrae, R. R. (1992). Revised NEO Personality Inventory (NEO Pl-R) and NEO Five-Factor Inventory (NEO-FF/) Professional Manual. Odessa, Florida: Psychological Assessment Resources. 
[61] Hogan, R., Johnson, J. \& Briggs, J. (1997). Handbook of personality psychology. San Diego: Academic Press.

[62] McCrae, R. R. \& Costa, P. T., Jr. (1997). Personality Trait Structure as Human Universal. American Psychologist, 52, 509-516. http://dx.doi.org/10.1037/0003-066X.52.5.509

[63] Springer, L., Stanne, M. E., \& Donovan, S. S. (1999). Effects of small-group learning on undergraduates in science, mathematics, engineering, and technology: A meta-analysis. Review of educational research, 69(1), 21-51. http://dx.doi.org/10.3102/00346543069001021

[64] Roeders P, (2005). Aprendiendo Juntos. 3ra ed. Lima: Editorial San Marcos.

[65] Suárez Guerrero, C. (2010). Cooperación como condición social de aprendizaje. Editorial UOC.
[66] Del Canto, P., Gallego, I., López, J. M., Mora, J., Reyes, A., Rodríguez, E., Sanjeevan, K., Santamaría, E., \& Valero, M. (2009). Conflictos en el trabajo en grupo: cuatro casos habituales. Revista de Formación e Innovación Educativa Universitaria. Vol, 2(4), 211-226.

[67] González, J. H. (2006). Construir una identidad: vida juvenil y estudio en el $\mathrm{CCH}$ Sur. Revista Mexicana de Investigación Educativa, 11(29), 459-481.

[68] Hernández, D. (2000). Proyecto de vida como categoría básica de interpretación de la identidad individual y social. Revista Cubana de Psicología, 17(3), 270-276.

[69] Erikson, E. H. (2000). El ciclo vital completado. Barcelona: Paidós.

[70] García-Alandete, J. (2013). Bienestar psicológico, edad y género en universitarios españoles. Salud \& Sociedad: investigaciones en psicología de la salud y psicología social, 4(1), 48-58.

[71] Fabry, J. (2001). Señales del camino hacia el sentido. Lag. México 